\title{
Damper and fish, tea and sugar: post-contact changes in resource use and residence on Groote Eylandt
}

\author{
Anne Clarke
}

Heritage Studies, Department of Archaeology, School of Philosophical and Historical Inquiry, The University of Sydney, News South Wales 2006, Australia. Email: annie.clarke@sydney.edu.au

\begin{abstract}
A number of the archaeological sites located and studied on Groote Eylandt were occupied during the very recent past covering the time of contact with Macassans and missionaries. Historical sources relating to the early period of the Church Missionary Society Mission from the 1920s to the 1950s are used in this paper to examine the material record and processes of cross-cultural interaction and change, rather than to recreate a generalised ethnographic past located at some unspecified point in the late Holocene.
\end{abstract}

KEYWORDS: Northern Australia, cross cultural interaction, Macassans, missionaries

\section{INTRODUCTION}

Sylvia Hallam, together with a number of her students, produced a series of important ethnohistorical accounts of Indigenous societies in Western Australia (papers this volume). These ethnohistories were by and large reconstructive, aimed at providing detailed accounts of precontact Indigenous economies and social systems. Collectively, these studies now provide a valuable historical archive in their own right and form a key element of Sylvia Hallam's contribution to Australian Indigenous studies. The paper presented here is part of a research project about the archaeology of cross-cultural interactions on Groote Eylandt in the Northern Territory of Australia. With this paper I would like to acknowledge Sylvia Hallam's contribution to archaeological scholarship by presenting this analysis of historical sources relating to the early period of the Church Missionary Society (CMS) Mission from the 1920s to the 1950s. However, rather than using these documents to construct a narrative of pre-contact Indigenous society, I will use them instead to present an analysis of post-contact changes in resource use, residence and technology.

A number of the archaeological sites located and studied on Groote Eylandt were occupied during the very recent past covering the time of contact with Macassans and missionaries (Clarke 1994, 2000a; Clarke and Frederick 2006). In this context, I would argue that the historical sources are better used to understand the material record and processes of cross-cultural interaction and change, rather than to recreate a generalised ethnographic past located at some unspecified point in the late Holocene. This is particularly the case in coastal Northern Australia where Indigenous people experienced at least 200 years of engagement with outsiders prior to the arrival of permanent European settlements and where recent archaeological research has identified substantial changes in resource use, settlement patterns and local environments from around 3,000 to 500 years ago and then from 500 years ago to the present (Bourke 2000; Brockwell 2001; Faulkner 2006; Hiscock 2008).

\section{GROOTE EYLANDT}

The Groote Eylandt archipelago in northern Australia is located about $630 \mathrm{~km}$ east of Darwin and $43 \mathrm{~km}$ east of the Arnhem Land coast, on the western side of the Gulf of Carpentaria. The Indigenous people of Groote Eylandt experienced contact through two distinctive groups of outsiders, firstly Macassan fishermen and then European missionaries.

The first cross-cultural encounters involved a seasonal bartering relationship with Indonesian fishing fleets from southern Sulawesi (Macknight 1976). The fishermen, often referred to as Malays in many 19th century texts, or more commonly as Macassans (Macassar was the major port of origin for many of the boats), came to northern Australia in search of commodities to sell in the 
marketplaces of island South-East Asia and beyond. The main focus of Asian commercial interest in the region was trepang (bêche de mer), but pearl shell, pearls, turtle shell, sandalwood, tin, manganese and dried shark tails were also sought after by the trepangers (Flinders 1814; Warner 1932; Berndt and Berndt 1954; Worsley 1955; Macknight 1976). The archaeology, history and operation of the trepang industry in Arnhem Land, or 'marege' (as it was called by the Macassans), has been described and analysed in extensive detail by Macknight (1969, 1972, 1976). Subsequent studies have broadened our knowledge of both the scope and social impact of the industry (Mulvaney 1975, 1989; Mulvaney and Green 1992; Mitchell 1994, 1996; Clarke 1994, 2000a, 2000b; Morwood and Hobbs 1997; Clarke and Frederick 2006).

The CMS established the Emerald River Mission in 1921 following the expeditions made by Warren and Dyer in 1916 and 1917 from the Roper River Mission (Warren 1918 in Macknight 1969: 186-203; Cole 1971: 20-28; Dewar 1992: 13). The Emerald River Mission was set up as a mission station for 'half-caste' children from the Roper River Mission to bring them up away from what was seen as the negative cultural influences of their 'native' families (Dewar 1992: 25-29). The first children from the Roper River arrived in 1924 (Cole 1972: 52), but by 1933 the population had dropped from the original 34 to only 9 children. The CMS then turned their missionary activities towards ministering to the local Groote Eylandt clans (Dewar 1992: 35).

In 1943, after the outbreak of World War II, the RAAF constructed an airstrip near the Mission and the CMS shifted to the present-day site on the Angurugu River (Cole 1983: 43). In 1978 the CMS handed over financial administration of the Mission to the Angurugu Council and in 1982 the Community Government Council was established (Cole 1983: 44-45).

In 1938 Fred Gray established the settlement of Umbakumba in Port Langdon. Gray had operated a fishing and trepanging boat in the coastal waters of eastern Arnhem Land since the early 1930s (Dewar 1992: 81-84.) In 1938 when Qantas built a flying boat base in Port Langdon to serve as a refuelling depot for the Sydney to London flight, the CMS approached Gray to work for them, to oversee the relationship between the Aboriginal population and the flying boat base staff. Gray preferred to remain independent of the CMS and received official permission to establish Umbakumba in 1940 (Dewar 1992: 82). Umbakumba was later taken over by the CMS who ran it from 1958 and 1966. In 1966 it was administered by the Welfare Branch and became self-governing in the 1980s (Cole 1983: 45-46).

\section{INITIAL ACCOUNTS OF GROOTE EYLANDT SOCIETY}

There are two published accounts of Groote Eylandt society that date from the first five years of the Emerald River Mission (1921-1926), one written by Norman Tindale (1925-26) and the other by G.H. Wilkins (1928).

\section{NORMAN TINDALE: 1921-1922}

Norman Tindale spent 15 months on Groote Eylandt and at the Roper River between 1921 and 1922 (Tindale 1925-26: 61). He lived on Groote Eylandt for six months from November 1921 to April 1922. He first accompanied the Reverend Warren in September 1921 on a boat trip around the island inspecting sites for the Mission Station and returned two months later with Alfred Dyer to the site of what became the Emerald River Mission on the west coast of Groote Eylandt. Even though Tindale was the first European to describe Groote Eylandt Indigenous society in any detail, one of the striking aspects of his account is the extent to which materials and artefacts introduced by Macassans had already been integrated into the existing material culture and economy. His observations were made only 15 years after the last season of Macassan visits in 1906 (Macknight 1976: 125).

Tindale (1925-26: 64) considered that three hundred people was a generous estimation of the island population. He recorded six local groups with the largest one located at Bartalumba Bay (Table 1). The Bartalumba group is recorded as having country on Bickerton Island as well as at Bartalumba Bay.

The Bartalumba group was the main group with sea-faring skills and they possessed most of the 25 sea-going canoes Tindale observed in operation around Groote Eylandt (Tindale 1925-26: 110). The Bartalumba group visited Caledon Bay and the Rose River and they also spoke Nungubuyu (Tindale 1925-26: 66). Their sea-going canoes were capable of making journeys of up to 30 miles (1928: 111) and Tindale notes that people had the navigational skills to sail out of sight of land.

TABLE 1

Local Groups Recorded by Tindale in 19211922

\section{LOCAL GROUP}

LOCATION

\begin{tabular}{ll}
\hline Bartalumbu & North-West \\
Yetiba & South-West \\
Talakurupa & East and South-East \\
Amakurupa & North-East \\
Pbara-pbara & North \\
Angoroko & West \\
\hline
\end{tabular}


Contact with the mainland appears to have been a regular occurrence, with trade and exchange being one of the main motivations. This trade went both ways with the Groote Eylandters trading fighting spears to mainland groups in return for bamboo spears from the Balamumu of Caledon Bay, emu feathers, red ochre and quartzite implements (Tindale 1925-26: 97). Tindale (1925-25: 97) noted how the Groote Eylandt spears would often pass inland, eventually being redecorated by the receiving groups, and he recounted seeing spears painted with Mara designs having faded traces of Groote Eylandt motifs underneath.

The red ochre imported from the mainland is described as originating from the country of Rembarunga in the interior of Arnhem Land (Tindale 1925-25: 116). The ochre occurs in both granular and amorphous forms and in several different shades. Despite Tindale's assertion that red ochre was only available from the mainland, both Rose and McCarthy observed the use of local ochre sources. Rose (1942: 170) noted, '... there is a considerable trade particularly in ochres from the mainland,' and specifically mentioned the import of pebble ochres from Caledon Bay. McCarthy (1960: 298-299) observed rolled pebbles of red and yellow limonites being collected from the bed of the Angurugu River and from laterites adjacent to quartzite outcrops.

Metal was another item brought from the mainland. Metal fishhooks were originally obtained from Macassans but Tindale (1925-26: 81) comments that in recent years metal from wreckage and from the mainland had provided a source of raw material for fishhooks. Two missionaries, Perriman and Dyer, also comment on how fencing wire and nails from the mission compound were constantly stolen by Groote Eylandters to make prongs for fishing spears and fishhooks (NTRS 226, TS 102/1: 7; NTRS 693/A). This is echoed by Tindale's (1925-26: 93) own observation that spear barbs made from either hardwood or the caudal spines of stingrays were largely replaced by fourpronged fencing wire soon after the establishment of the Emerald River Mission. Perriman also recounts that three and a half inch nails were used to make fishhooks in the early mission days (NTRS 226, TS 102/1: 7). Tindale provides a story of how a steel tank discarded somewhere in the Gulf was cut up by the local Aboriginal people and that several pieces were later obtained by the Groote Eylandters who ground and shaped them into shovel-nosed spears (1925-26: 98).

Fine-grained quartzite knives (blades) and spearheads were also imported from the mainland as there were no suitable stone sources on Groote Eylandt. Thomson (1949) and later, Jones and White (1988) described the stone industry based on the famous Njilipitji quartzite blade quarries of the Walker River. This seems the likely source for materials imported onto Groote. Tindale states (1925-26: 98) that stone came to Groote after passing through groups located much further to the south (Allawa, Ngalakan, Mara and Nungubuyu). This may mean that another more southerly source is involved in stone trade or that this is the direction that stone materials moved through the exchange cycle before travelling to Groote Eylandt.

Bush foods were observed to be plentiful with the coast being the focus of subsistence and camping activities (Tindale 1925-26: 76-84, 113-115). Cycad nuts were the main plant food and were made into dampers after processing in streams. Yams (Dioscorea transversa) were dug up from black soil swamps and a range of fruits including Eugenia sp. (now Syzygium sp.) and Buchanania sp. were also eaten.

Dugong was an important source of animal food for people on the north and west coasts and turtles and turtles' eggs were important animal foods on the southern and eastern coasts (Tindale 1925-26: 78). The dugong was hunted from canoes using harpoons (Tindale 1925-26: 78) and hunting occurred on still nights. Turtles were harpooned during the day and were also commonly taken when egg-laying (Tindale 1925-26: 79).

Other animals, which were hunted, included tortoises, agile wallabies, bandicoots, rats, lizards, echidnas, possums and flying foxes (Tindale 192526: 80). Birds such as native companions, jabirus and black cockatoos were hunted and seabird and turtle eggs were collected from offshore islands (Tindale 1925-26: 80, 111). The eggs and young chicks of scrub fowls were also taken from mounds (Tindale 1925-26: 80). Shellfish (Arca trapezia) were seen being collected by the canoe load to be cooked or eaten raw before being discarded in large mounds around Bartalumba Bay (Tindale 1925-26: 82).

Tindale made a number of observations, which relate to the consequences of contact:

Fish ('akwaia') are plentiful around the island, and various devices are employed to catch them, fishing over the reefs with hook and line being the principal mode. Bait is obtained by digging out of the sand with the hands various beach crabs (Ocypoda). They are usually dismembered and placed in a bark dish shielded from the sun. The canoe is anchored over a suitable spot, the hooks baited with the fleshy part of the crab, the hard parts being used as ground-bait. The line is made of hibiscus bark cord, and the presentday hook is an iron nail ('biangi'). Endeavours were made to find out what hooks were in use previously, but they have obtained metal for so long a period, from Malay traders, from wreckage, and in recent years by trade from mainland tribes, that no other hooks are now known. (Tindale 1925-26: 80-81) 
What is of interest from this account is that only metal hooks were used for line fishing. Because of the long history of access to metal, people had no memory of what material was used to make hooks in earlier times. No shell fishhooks or blanks were identified from the archaeological deposits and my own enquiries to people about non-metal hooks solicited the information that eagle or possum claws were used. While this is quite feasible from a technical point of view, it also seems unlikely given the number of eagles, possums and claws that would be needed to sustain daily supplies of hooks for line fishing. Dyer (NTRS 639A: 7) noted, '... plenty of fish caught on their lines made with bark and a bone fish-hook'. Another explanation is that prior to Macassan contact, line fishing was not a major component of subsistence practices, and fish were either speared or caught in tidal traps. The use of fishing nets was not observed either (Tindale 1925-26: 81).

Tindale's description of Groote Eylandt society is important because it dates from the first few months of the permanent presence of Europeans on the island. He was in a unique position, able to describe a society poised on the brink of a fundamental transition from hunter-gatherer to 20th century western, Christian, capitalism. But while his ethnography can be regarded on one hand as a conventional description of a traditional hunter-gatherer society, it is also clear that Groote Eylandt culture had already experienced transformations in the realm of technology and had experienced at first hand a different world view presented by Macassan fishermen who demanded labour in return for material possessions and who had a much greater geographical and political knowledge of the world (Worsley 1954: 13-14). These experiences should not be under-estimated in terms of their impacts on the existing indigenous social institutions and practices (Clarke 2000b).

\section{CAPTAIN G.H. WILKINS - 1925}

In 1925 Captain Sir George Hubert Wilkins spent two months on Groote Eylandt as a part of his faunal collecting expedition for the British Museum (Natural History). On his return he wrote Undiscovered Australia, an anecdotal account of his expedition (Wilkins 1928). The text is typical of its genre, full of judgemental, negative observations about Indigenous people, their lives and motives for action. The missionaries are inevitably written about as honest, Christian toilers and the 'natives' as untrustworthy, dirty, on the make, but possessed of uncanny bush skills. The anecdotes are, however, occasionally tempered by an almost anthropological willingness to observe and participate in the daily lives of the people he encountered. There is one such episode described from Groote Eylandt that provides some valuable information about some of the impacts of contact with the Missionaries.

Wilkins arrived at the Emerald River Mission Station in February 1925 towards the end of the wet season and found that the missionaries had relatively little contact with the island population, their mission being chiefly concerned with 'halfcaste' children moved from the mission at the Roper River. In the course of his stay Wilkins did have several encounters with Groote Eylandt people including one camping trip lasting several days. This trip is the most interesting of his anecdotes in terms of the observations he made of people living in the bush away from the Mission (Wilkins 1928: 242-251).

Wilkins left the Emerald River and went north to the Angurugu River and describes walking six miles inland to a series of rapids. This may well be the area occupied by the present day settlement of Angurugu. After spending two days back on the coast in the company of two men he met up with a man he called Yarra (Wilkins 1928: 242). Yarra spoke a little English and Wilkins arranged to spend a few days with his group.

The group of men and boys walked inland with Wilkins and although it is not entirely clear where he went, it seems that he travelled into the range of quartzite hills north of Angurugu. They camped at the foot of a range of hills in caves described as follows:

It is evidently a much-used camping site, and the walls of the caves were covered with many drawings representing men and women, kangaroos, fish, turtle, dugongs, native canoes and Malay prows, modern sailing boats, and many stencilled hands and arms. (Wilkins 1928: 245)

Whilst camped at the cave the men continued to paint:

One conspicuous and rather well executed drawing depicted the arrival of the Mission boat at Groote Eylandt. On the deck of the lugger with sails set were men heaving at an anchor. A man dressed in a cassock stood at the helm, and below decks, showing through the walls of the boat, were two women wearing hats. Another spirited drawing was of two men shaping up and wearing boxing gloves. Action was clearly shown and the men were represented as being in the air. The natives explained that they had seen two of the boys at the Mission Station engaged in a boxing contest. (Wilkins 1928: 246)

During the few days that Wilkins camped with 
this group, people collected only sugar bag (honey) and palm hearts (1928: 250).

The photographs taken of people in camp show items of both indigenous and introduced technology (Wilkins 1928: plates facing 210, 236, 240, 244). There is a billycan, some tin cans and pieces of cloth visible in the camps, alongside slabs of paperbark, stringybark coverings, wooden shelters and a spear thrower. Wilkins also mentions that the women showed him tin cans incised with designs made by iron knives. When the women went off to collect bush foods they took their knives, dilly bags and digging sticks. He also describes how Yarra shaved himself using flakes of glass: '... so he uncovered a broken bottle from the sandy floor of the cave, and, chipping small fragments from it with his tomahawk ...' (Wilkins 1928: 249).

This anecdote is particularly revealing because it shows the introduced items, the glass bottle and the tomahawk (which I am assuming to be a metal axe as tomahawk is the colloquial term in the Northern Territory for a short-handled metal axe), being used in a traditional context. The tomahawk is used to take a chip off a glass bottle, which is then used to shave. The bottle is not used as a container and the hard axe head is used as a hammerstone to make a flake. Dyer also recounts seeing men shave themselves with stone flakes (NTRS 693/A).

Wilkins considered that he was the first white man to have lived in a camp with Aboriginal women on Groote Eylandt. On a voyage around the island with Mr Warren he only saw women in the distance in the sand hills or behind their stringybark covers. He mentioned several times how Groote Eylandt men kept the women away from both the missionaries and other Europeans and described how on first meeting him the women in Yarra's camp covered themselves with bark slabs. During his stay with Yarra he had further contact with the women who showed him their decorated tin cans and went about their daily activities in camp in his presence without their bark covers.

Wilkins' account is valuable because his observations and photographs provide some documentation about the extent and consequences of contact four years after the establishment of the Emerald River Mission. It is apparent that people had a familiarity with the Mission, had learnt some English, and had taken introduced items of material culture into their everyday lives while still maintaining seasonal patterns of resource use and residence. When Wilkins went into the bush with Yarra it was towards the end of the wet season, the swamps were full, people were camping in caves and constructing bark huts to keep the rain off.

On the east coast Wilkins saw gangs of Aboriginal men working for two young Australian trepangers in return for flour and tobacco. The two men had been camped on Groote Eylandt for two years. These two men were probably Bill Harney and Horace Foster who had camps on Groote Eylandt and in Caledon Bay (Berndt and Berndt 1954; G.R. Harris in NTRS 1098/P1). Further down the east coast he met with another group of people who spoke a little English and with whom he traded tobacco for stone spears and spear throwers. These east coast groups are the people who made up the population of Umbakumba some thirteen years later and whose social relations of production Rose (1987: 51) considered to still be largely intact and unaffected by contact in 1940, even though from this account this was clearly not the case.

\section{ASPECTS OF MISSION LIFE: 1939-1954}

The Church Missionary Society Archives (located in the Northern Territory Archives, Darwin) contain records relating to the Angurugu Mission from 1939 onwards. The archives also contain mission report books from Umbakumba for the period of 1958-1965 when the CMS took over the administration of the settlement from Fred Gray. The records for the earlier Emerald River Mission are missing, reportedly destroyed in a fire. These records were in existence in the late 1940s/early 1950s as Ronald and Catherine Berndt, who visited Angurugu briefly in 1947 (NTRS 1098/P1), make reference to them in their chapter notes to Arnhem Land. Its History and Its People (Berndt and Berndt 1954).

\section{FOOD}

Major changes in food procurement and consumption have occurred since Tindale and Wilkins' $^{\prime}$ accounts from the 1920s, not the least being the availability of processed foods initially distributed as rations and now sold at the stores. Turner (1974: 175) considered that with the establishment of the Mission, people could attain a higher level of subsistence for less effort than that required to extract food resources from the bush. However, as can be seen from the discussion below the reality was slightly more complex as the regular provision of an adequate diet was not always guaranteed (for example Worsley 1954: 285; McArthur 1960a: 20-26) in the early days of the Angurugu and Umbakumba settlements.

The mission archives record the constant struggle to feed around two to three hundred people from imported stores and from the produce of the vegetable garden. In 1947 G.R. Harris prepared these notes detailing daily rations for the Mission inhabitants:

Breakfast Men $4 \mathrm{oz}$ flour, $4 \mathrm{oz}$ porridge or $2 \mathrm{oz}$ rice. Women $2 \mathrm{oz}$ flour and $4 \mathrm{oz}$ porridge and $2 \mathrm{oz}$ flour and same for children. Dinner Men $4 \mathrm{oz}$ and women and children $2 \mathrm{oz}$ flour, on average of 
12oz sweet potatoes or cassava or ration porridge. Supper Men 4oz flour, women and children $2 \mathrm{oz}$ flour and fish or ration vegetables, porridge, or rice. Vegetables and fish are issued raw. A ration of tea and sugar is issued once daily to all adults. There are no rations issued on Saturday except to dormitory girls for breakfast and cow and goat herds. No midday meal is given out on Sunday but peanuts are issued when available. August 1947. (NTRS 1098/P1)

Margaret McArthur (1960a: 14-26) also looked at the diet of Aboriginal people living on the Mission Stations in 1948 as part of her research on the 1948 Australian-American Scientific Expedition to Arnhem Land. She observed the following distribution of rations at Angoroko (Angurugu):

Breakfast: Ground-wheat porridge, sweetened with golden syrup or honey; damper; tea and sugar.

Dinner: Wheat porridge or rice; fresh vegetables or golden syrup or honey; damper; tea and sugar.

Supper: Damper and fish; tea and sugar. (McArthur 1960a: 15)

Animal protein, vegetables and fruit barely figure in this official diet, which consists largely of processed carbohydrates. Men fished every day and at other times went hunting wallabies, turtles and dugongs (see below). This provided the Mission Station with much needed sources of fresh protein:

Today the fishermen caught five turtle. During the month the fishermen have caught sufficient turtle to make quite an appreciable difference in the protein diet of the people. K.D. Hoffman, Wednesday, 26 August 1953 (NTRS 1098/P1)

Perriman recalls how people were paid for fish, turtle meat, turtle eggs and dugong (NTRS 226, TS 102/1: 20). In the first years of the Emerald River
Mission the native Groote Eylandt population did not get paid from Mission food stores for work or for bush produce but were remunerated with consumer goods such as tobacco, knives, fencing wire, nails and tomahawks (NTRS 226, TS102/1: 7). With the establishment of credit stores people were able to build up credit accounts for the purchase of goods (Worsley 1954: 296). At the Mission, rations were also only distributed to those who attended services (Worsley 1954: 290).

Although precise quantities are not given for rations of fish, tea and sugar and on some days rice would substitute for porridge or vegetables, a rough guide to percentage contributions of the various foodstuffs to the overall diet can be made (Tables 2-4). There are some monthly records of fish numbers brought into the mission (see Table 9 below). These numbers only represent those sold to the missionaries for distribution and it is more than likely that most fish went straight into the community for consumption. Given that around 200 people were recorded on the Mission in 1947, monthly totals of between 315-1380 fish barely provide each person with one fish per week. A comment recorded at a much later date in the Umbakumba Mission Report for June 1958 seems to confirm this:

14th Walkabout day. Hart fishing in the afternoon 16 fish caught in about an hour. Man in canoe caught about 200 fish, this was second load of fish for the canoe. This proves what we have long suspected that there are a lot of fish about. It would be impossible at the present to find out how much fish comes into the camp other than what the fishermen bring in. The people catch fish everyday and the produce book is no real indication as to the amount of fish brought in. K.W. Hart (NTRS 1101/P1)

McArthur noted that even though both Umbakumba and Angurugu had vegetable gardens their produce was not consistently available (McArthur 1960a: 14-16). In 1948 when the nutrition

TABLE 2

Average daily diet at Angurugu in 1947 (the fish ration is unspecified so I have used an arbitrary figure of $12 \mathrm{oz}$, the equivalent to a ration of sweet potatoes).

\begin{tabular}{lllll} 
FOODS & $\begin{array}{l}\text { AVERAGE DAILY DIET } \\
\text { FOR MEN }\end{array}$ & \multicolumn{2}{l}{$\begin{array}{l}\text { AVERAGE DAILY DIET } \\
\text { FOR WOMEN \& CHILDREN }\end{array}$} \\
\hline & WEIGHT (oz) & $\%$ & WEIGHT (oz) & $\%$ \\
Flour & 12 & 30 & 6 & 18 \\
Porridge & 4 & 10 & 4 & 12 \\
Sweet Potato/Cassava & 12 & 30 & 12 & 35 \\
Fish & 12 & 30 & 12 & 35 \\
\hline
\end{tabular}


TABLE 3 Numbers and percentages of foodstuffs consumed on Groote Eylandt (taken from Rose [1987: 50, table 1]).

\begin{tabular}{lll} 
FOODS & $\begin{array}{l}\text { NUMBER OF } \\
\text { VARIETIES }\end{array}$ & $\begin{array}{l}\text { PERCENTAGE OF TOTAL } \\
\text { FOODSTUFFS CONSUMED }\end{array}$ \\
\hline Land animals (including reptiles) & 15 & 5 \\
Birds (land and sea) & 76 & 25 \\
Freshwater and marine animals and fish & 97 & 31 \\
Shellfish (mussels, crabs, etc) & 39 & 13 \\
Plants & 82 & 26 \\
\hline \multirow{2}{*}{ TOTALS } & 309 & 100
\end{tabular}

team was based at Umbakumba, the harvest was not yet in progress and because of pressure on resources around the settlement, people had to travel for several days to get bush foods. Worsley (1954: 279-294) noted that although a large garden was under production at Umbakumba it was not particularly productive and people resented being made to work in it.

McArthur (1960a: 20-26) assessed the nutritional status of the official ration and found it did not provide adequate levels of calories, protein, and minerals. Men carrying out physical labour, breast- feeding mothers, and babies older than 15-18 months were noted as having particular nutritional needs that were not met by the general ration allowance. She further commented (1960a: 25-26) that the need to provide a diet regarded as adequate by European standards for a native population was not generally appreciated and that the quantity and quality of the ration allowance was related to a perception that because people were not considered to work as hard as their white counterparts they did not need or deserve an equivalent level of subsistence.

TABLE 4 Percentage contributions of different foods to the total Anbarra diet 1972-1973 (collated from Meehan [1982: 153-155, tables 29-32]). p-present, not measured

\begin{tabular}{lllllllll} 
FOODS & SEPTEMBER & \multicolumn{3}{l}{ JANUARY } & APRIL & \multicolumn{3}{c}{ MAY } \\
& 1972 & & 1973 & & 1973 & & \\
& $\%$ GROSS & $\%$ & \% GROSS & $\%$ & $\%$ GROSS & $\%$ & $\%$ GROSS & $\%$ \\
& WEIGHT & $\mathrm{kcal}$ & WEIGHT & $\mathrm{kcal}$ & WEIGHT & $\mathrm{kcal}$ & WEIGHT & $\mathrm{kcal}$ \\
Shellfish & 24.3 & 3.6 & 48.5 & 8.9 & 30.0 & 4.5 & 20.8 & 2.5 \\
Mangrove worms & 0.6 & 0.5 & - & - & 0.1 & $\mathrm{p}$ & - & - \\
Crustacea & 14 & 0.6 & 1.2 & 0.7 & 2.2 & 1.0 & 2.3 & 0.9 \\
Grubs & 0.5 & $\mathrm{p}$ & - & - & - & - & 0.1 & $\mathrm{p}$ \\
Fish & 22.4 & 22.0 & 21.5 & 25.8 & 21.9 & 21.4 & 42.0 & 33.6 \\
Reptiles & 10.2 & 9.5 & 2.0 & 2.2 & 3.8 & 3.5 & 3.5 & 2.7 \\
Birds & 3.1 & 5.8 & 0.9 & 2.1 & 0.3 & 0.6 & 0.4 & 0.7 \\
Mammals & 8.8 & 17.8 & 5.5 & 13.6 & 0.4 & 0.9 & - & - \\
Fruits and Nuts & 14.3 & 3.0 & 7.3 & 4.5 & 12.1 & 1.7 & 0.8 & 0.5 \\
Vegetables & 0.6 & 0.7 & 0.4 & 0.5 & 7.0 & 8.1 & 4.3 & 4.1 \\
Ant bed & 0.05 & $\mathrm{p}$ & - & - & 0.1 & $\mathrm{p}$ & - & - \\
Honey & 0.8 & 1.2 & - & - & 0.3 & 0.4 & 0.1 & 0.1 \\
Bought Foods & 13.3 & 35.2 & 12.8 & 41.8 & 21.9 & 57.8 & 25.4 & 55.1 \\
\hline
\end{tabular}


Worsley (1954: 288) recorded how the Umbakumba people interpreted their poor and monotonous diet as due to, 'parsimony, idleness or malice', on the part of whites who they considered had access to the financial means to provide better food. At Umbakumba the provision of rations as cooked food was seen as another form of control and regimentation (Worsley 1954: 289).

McArthur (1960b: 126-134; McCarthy and McArthur 1960) attempted to quantify the dietary intake of people camped in the bush. She camped with people at Hemple Bay in Port Langdon and South Bay on Bickerton Island and found that, allowing for seasonal and regional variations in plant and animal productivity and her acknowledged problems in quantifying all the food, peoples' diet was well-balanced and generally exceeded daily nutritional requirements. In Hemple Bay the weight of animal foods was 2.3 times that of vegetable foods. On Bickerton Island vegetable foods outweighed animal foods by a factor of 1.7, but a lot of fish and turtle was brought into the camp and distributed before it could be weighed.

Table 2 shows that the official mission diet consists primarily of carbohydrates, approximately $70 \%$ for men and $65 \%$ for women and children. It is interesting to compare the mission diet with that recorded by Meehan (1982) for the Anbarra, a hunter-gather group from the north-central coast of Arnhem Land. Meehan's figures (see Table 4) show, that over the period of observations, protein sources provided the largest component of the diet both by weight and energy input. In September 1972, for example, the combined protein sources formed $73.2 \%$ of the diet by weight and $59.8 \%$ by energy input. This pattern is almost the reverse of the diet provided through mission rations.

Meehan (1982: 159-160) has shown that although shellfish only provided $2.5-8.9 \%$ of the energy input to the diet they nonetheless formed what she characterised as a low-key and dependable source of fresh protein throughout the year. She also looked at the social importance of shellfish both in terms of how people perceived their overall role in the diet and as a resource collected by a wide range of community members, including old or pregnant women, who tended to be less active or mobile in their involvement in other food procuring activities.

As noted above, neither shellfish nor fruits were taken into account in the mission reports of bush foods coming into the settlement and yet it is likely that women, when they could get away from domestic duties and working in the gardens, would collected a whole variety of shellfish and plant foods from local shellbeds, swamps and jungle patches. Yams (Dioscorea transversa and $D$. bulbifera, Levitt 1981: 136-137) were collected from nearby jungle patches, and from the comments of the Superintendent it is clear that when available provided an important supplement to the diet:

Unknown quantity of yams. Good health probably attributable to adequate ration of wholemeal and large quantity of yams obtained from the jungle - fresh hunting grounds. (December 1943, NTRS 1098/P1, Box 1)

During April the bush yams have matured in the ground and particularly during Easter and over weekends people have made many excursions to neighbouring jungles to collect this food. (April 1952, NTRS 1098/P1)

McArthur (1960b: 19) noted that when the dormitory girls from Umbakumba were taken for picnics on the weekends they mainly collected small fish and shellfish. Under the regime of rations and enforced 'walkabouts', shellfish would have provided easily accessible and dependable sources of fresh protein as described by Meehan.

When the mission stores ran low and the supply boat failed to arrive as scheduled, the Aboriginal population was sent out on what the Mission Superintendent called 'Walkabout'. This appears to have lasted for periods of up to a month. Similarly at Umbakumba people were sent away from the settlement when stores of staple products such as flour ran out (Worsley 1954: 285):

Following the failure of supplies in July the majority of the people went walkabout until the stores arrived on the M.V. Cora Monday 21st August. K.D. Hoffman, August 1950. (NTRS 1098/P1)

The 'family' was considerably reduced in numbers during the month on account of low stocks of foodstuffs and lateness of growing crops. S.J.G. Hodge per G.R. Harris, April 1948. (NTRS 1098/P1)

Worsley (1954: 289-291) records how resentful people became at being sent out on weekends to get their own food. On these weekends people were also under pressure to collect shells and other bush products for sale, so that food collecting was not the only priority (Worsley 1954: 290). The area around Umbakumba was not regarded as being particularly rich in bush foods, and as people only had a weekend over which to travel it became increasingly difficult to find food around the settlement.

Bickerton men regularly left the Mission to spend time back on Bickerton Island and there are a number of accounts in the records about how they caught and consumed traditional sources of food: 
During the two months the Bickerton men were on Walkabout they reported having killed 11 dugong. Also consumed several hundred turtle eggs. (K.D. Hoffman, July 1950, NTRS 1098/P1)

20 men returned from Bickerton with 3 Dugong. (October 1951, NTRS 1098/P1)

Appended to many of the monthly reports were records of 'Native Foods' brought onto the Mission. I have tabulated these according to food type (Tables 5-9). The records are rather sporadic and there is no indication as to whether this is due to record keeping or a lack of bush food entering the Mission. It is also difficult to interpret whether the observable trends represent seasonal availability, a direct response to the needs of the Mission or mobility on and off the Mission. As with fish (see above), the quantities of food probably represent only a fraction of the total bush foods consumed by people. Despite these reservations there are some general comments that can be made.

Turtles (Table 6) were caught all year round, but on average more turtles were taken in the late dry season. As men regularly departed for Bickerton Island in the early dry season, this may be a contributing factor. Turtle eggs were available from March to December (Table 5). There is a dramatic increase in the wallaby catch from 1952 onwards, probably linked to the availability of rifles for hunting. In 1953 there is an entry in the monthly records about some boys using the mission rifle and getting lots of wallabies (Table 7). It may also indicate a greater degree of sedentism around the Mission with people supplementing their mission rations and their income by hunting in the surrounding jungles and forests. Dugong is also recorded more frequently from 1950 onwards (Table 8). As with wallabies the more frequent recording of dugong may reflect increasing sedentism with people bringing their catch back to the Mission. Other species, including shark, porpoise, duck, pigeon, flying foxes and crabs are all recorded but as these are rare occurrences I have not tabulated them individually (Table 8). It is likely that these were mostly consumed at beach camps.

Only a small selection of native foods (turtle, turtle eggs, dugong, wallabies, fish and yams) are consistently referred to in the Mission reports. While this is partly an artefact of missionary observations, it is also, I believe, an indication of the cultural importance of these particular foods.

The archives, supported by ethnography, show that one result of prolonged contact has been a reduction in the range of food resources consistently gathered. Although there is an obvious relationship between the abandonment of certain foods, such as cycad bread, which require a huge effort to process, and the accessibility of European equivalents such as damper and bread, it is not

TABLE 5 Record of turtle eggs brought onto the Angurugu Mission.

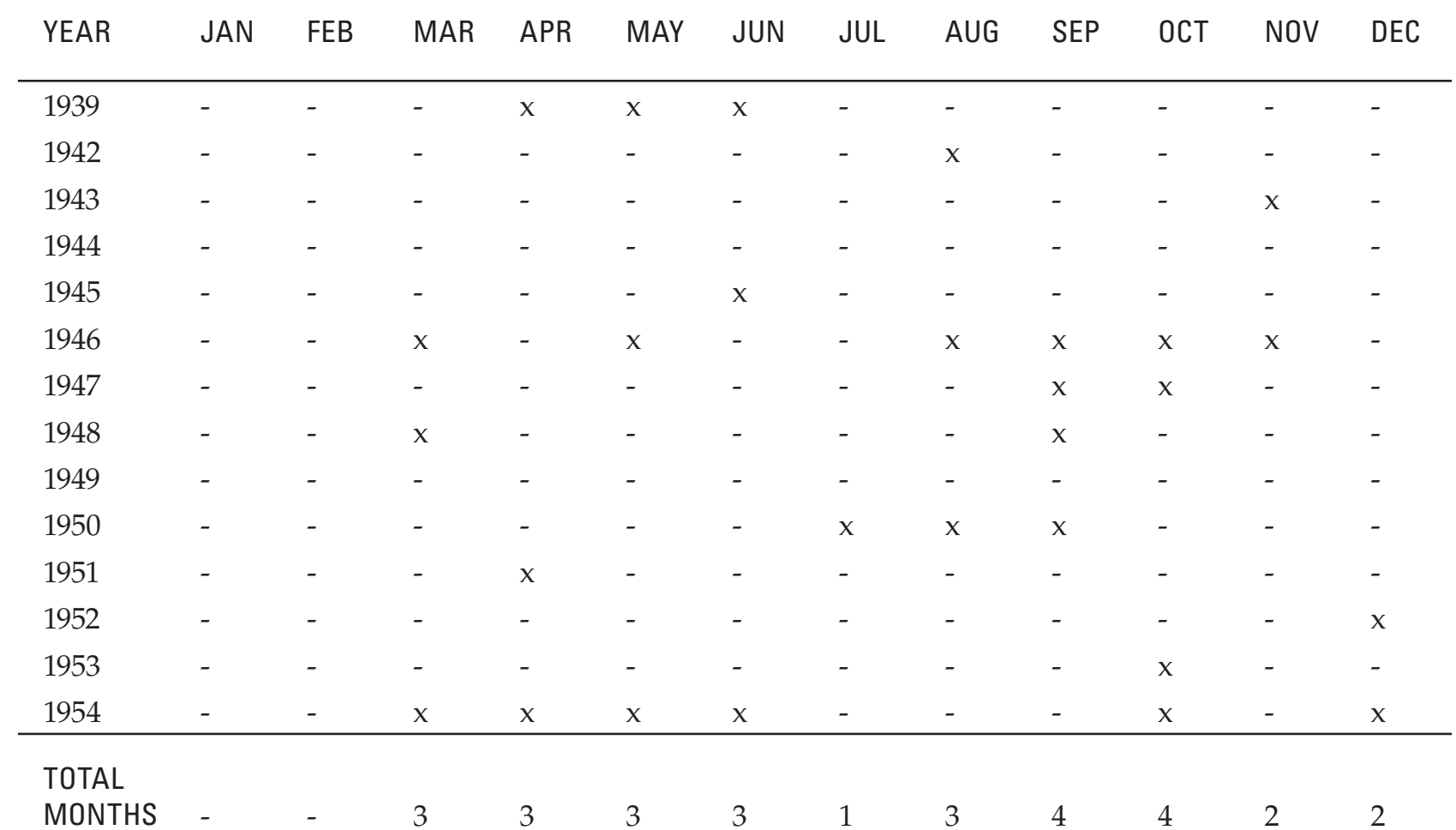


TABLE 6 Record of turtles brought onto the Angurugu Mission.

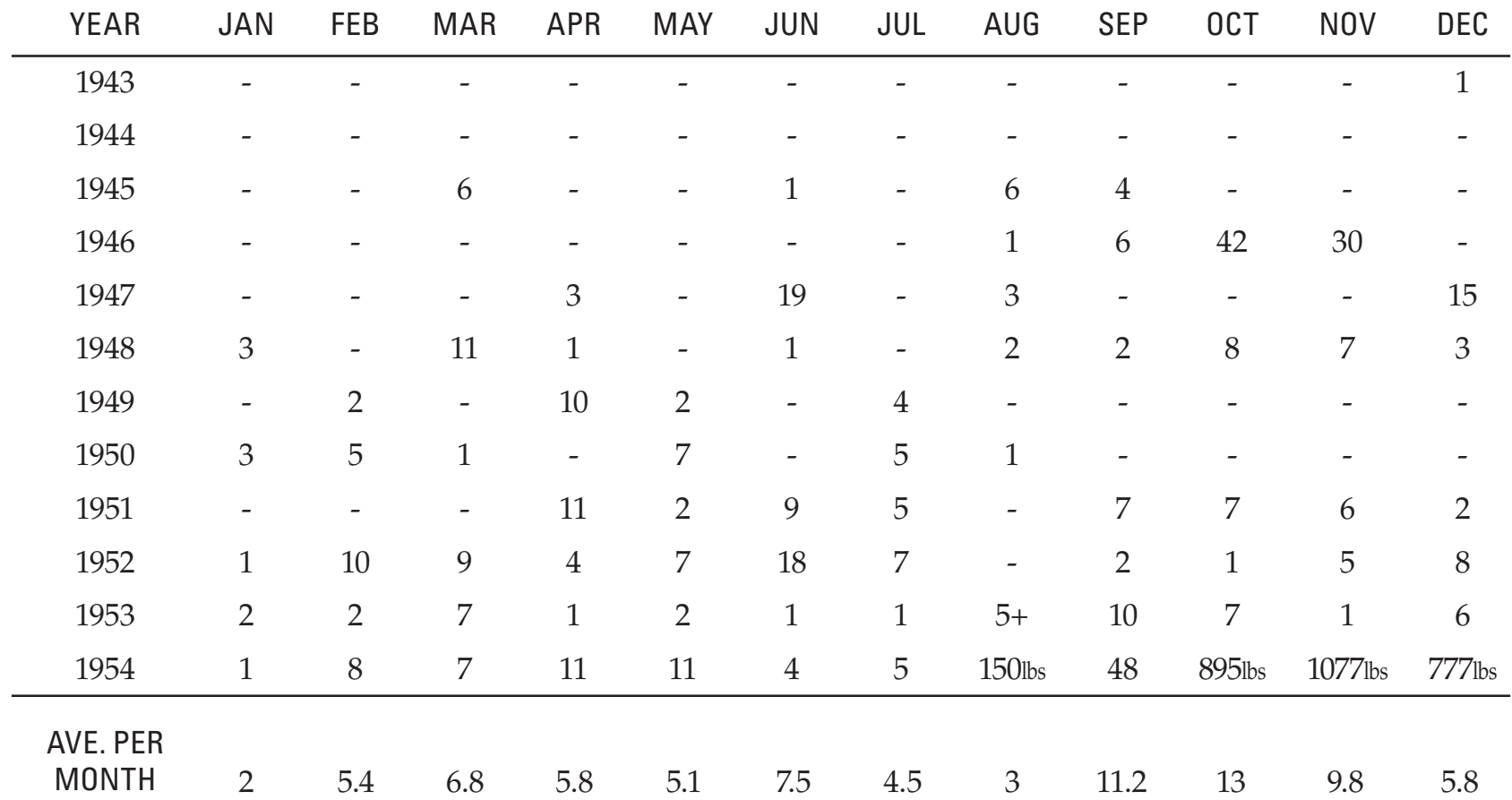

TABLE 7 Record of wallabies brought onto the Angurugu Mission.

YEAR JAN FEB MAR APR MAY JUN JUL AUG SEP OCT NOV DEC

\begin{tabular}{|c|c|c|c|c|c|c|c|c|c|c|c|c|}
\hline 1939 & - & - & - & $x$ & $x$ & $x$ & - & - & - & - & - & - \\
\hline 1940 & - & - & - & - & - & - & - & - & - & - & - & - \\
\hline 1941 & - & - & - & - & - & - & - & - & - & - & - & - \\
\hline 1942 & - & - & - & - & - & - & - & - & - & - & - & - \\
\hline 1943 & - & - & - & - & - & - & - & - & - & - & - & - \\
\hline 1944 & 8 & 14 & - & - & - & - & - & - & - & - & - & - \\
\hline 1945 & - & - & 18 & - & - & 6 & - & - & - & - & - & 16 \\
\hline 1946 & - & - & - & - & - & - & - & - & - & - & - & - \\
\hline 1947 & - & - & - & - & - & - & - & - & - & - & - & - \\
\hline 1948 & - & 2 & 2 & - & - & - & - & 4 & - & - & - & 11 \\
\hline 1949 & - & - & 13 & - & - & - & - & - & - & - & - & - \\
\hline 1950 & - & - & - & - & - & - & - & - & - & - & - & - \\
\hline 1951 & - & - & - & - & 4 & 10 & 4 & - & 3 & - & - & 8 \\
\hline 1952 & 16 & 12 & 12 & 12 & 8 & - & 3 & 16 & 5 & 18 & - & 5 \\
\hline 1953 & 45 & 10 & 12 & 5 & 12 & - & 33 & - & 17 & 22 & 16 & 15 \\
\hline 1954 & 20 & 74 & 29 & 21 & 28 & 16 & 15 & 670lbs & $443 \mathrm{lbs}$ & 657lbs & $20 \mathrm{lbs}$ & $357 \mathrm{lbs}$ \\
\hline $\begin{array}{l}\text { AVE. PER } \\
\text { MONTH }\end{array}$ & 22.3 & 22.4 & 14.3 & 12.6 & 20.8 & 10.6 & 13.8 & 10.0 & 8.3 & 20.0 & 16.0 & 11.0 \\
\hline
\end{tabular}


TABLE 8 Record of dugong (dg), shark (s), flying fox (ff), duck (d), porpoise (p), pigeon (pg) and crab (c) brought onto the Angurugu Mission.

\begin{tabular}{|c|c|c|c|c|c|c|c|c|c|c|c|c|}
\hline YEAR & JAN & FEB & MAR & APR & MAY & JUN & JUL & AUG & SEP & ОСТ & NOV & DEC \\
\hline 1946 & - & - & - & - & - & - & - & - & - & $1 \mathrm{dg}$ & $1 \mathrm{dg}$ & - \\
\hline 1947 & - & - & - & - & - & - & - & $1 \mathrm{dg}$ & - & - & - & $2 s$ \\
\hline 1948 & $1 \mathrm{dg}$ & - & - & - & - & - & - & - & - & - & - & - \\
\hline 1949 & - & - & - & - & - & - & - & - & $400 \mathrm{ff}$ & - & - & - \\
\hline 1950 & - & - & - & $\begin{array}{c}100 \mathrm{lbs} \\
\mathrm{dg}\end{array}$ & $\begin{array}{c}100 \mathrm{lbs} \\
\mathrm{dg}\end{array}$ & $\begin{array}{c}\text { 100lbs } \\
\mathrm{dg}\end{array}$ & - & - & - & - & - & - \\
\hline 1951 & - & - & - & $1 \mathrm{dg}$ & $2 \mathrm{~d}$ & $3 \mathrm{dg}$ & - & - & $1 \mathrm{dg}$ & $12 \mathrm{dg}$ & $3 \mathrm{dg}$ & $5 \mathrm{dg}$ \\
\hline 1952 & $\begin{array}{c}\text { 100lbs } \\
\mathrm{dg}\end{array}$ & $\begin{array}{l}\text { 60lbs } \\
\mathrm{dg}\end{array}$ & - & - & $1 \mathrm{dg}$ & $2 \mathrm{dg}$ & - & - & $\begin{array}{c}\text { 100lbs } \\
\mathrm{dg}\end{array}$ & $3 \mathrm{dg}$ & - & $1 \mathrm{dg}$ \\
\hline 1953 & - & - & $\begin{array}{l}1 \mathrm{dg} \\
+1 \mathrm{p}\end{array}$ & $\begin{array}{l}1 \mathrm{dg}+ \\
20 \mathrm{pg}\end{array}$ & 30lbs c & - & $1 \mathrm{dg}$ & - & - & $1 \mathrm{dg}$ & - & $1 \mathrm{dg}$ \\
\hline 1954 & - & $1 \mathrm{dg}$ & - & - & - & - & - & $\begin{array}{c}1840 \mathrm{lbs} \\
\mathrm{dg}\end{array}$ & - & - & - & $\begin{array}{c}920 \mathrm{lbs} \\
\mathrm{dg}\end{array}$ \\
\hline
\end{tabular}

such a simple correlation. Yams and sugar bag (honey) both require a degree of hard physical labour to acquire them and women will collect shellfish or Eleocharis dulcis for several hours without a break until enough has been gathered to eat and take back to camp or the settlement. Cultural preference for a particular range of foods is also a strong motivating factor in directing the amount of effort people are willing to put into hunting and gathering.

The favouring of particular foods today may also be a consequence of the changeover to weekend bush trips. If, as Worsley has noted people were under economic pressure to collect bush products to accumulate credit at the store then they may have begun to target the sorts of species which are either known to produce a large amount of food or which occur in great abundance in restricted

TABLE 9 Record of numbers of fish brought onto Angurugu Mission 1939-1946.

\begin{tabular}{ccccccccccccc} 
YEAR & JAN & FEB & MAR & APR & MAY & JUN & JUL & AUG & SEP & OCT & NOV & DEC \\
\hline 1939 & - & - & - & $\mathrm{x}$ & $\mathrm{x}$ & $\mathrm{x}$ & - & - & - & - & - & - \\
1940 & - & - & - & - & - & - & - & - & - & - & - & - \\
1941 & - & - & - & - & - & - & - & - & - & - & - & - \\
1942 & - & - & - & - & - & - & - & - & - & - & - & - \\
1943 & - & - & - & - & - & - & - & - & - & - & $x$ & - \\
1944 & 1270 & 1380 & 1060 & 600 & 755 & 275 & 480 & 430 & 620 & 640 & 734 & 315 \\
1945 & 180 & 410 & 990 & 620 & 510 & 1070 & 760 & 1280 & 690 & 320 & 160 & 690 \\
1946 & - & - & - & - & - & - & - & 707 & - & - & - & - \\
\hline
\end{tabular}


localities thus obviating the need for travelling long distances over a weekend. Anadara and Marcia species for example, occur in dense shell beds in muddy/sandy substrates in the intertidal zone and are easy to collect in large quantities. The same can be said for Pandanus spiralis kernels which although time consuming to process can be harvested in large quantities from restricted locations. Turtles and their eggs also provide conveniently packaged food in bulk. Two nests would provide two hundred or more eggs. One turtle, if caught whilst egg-laying, as is the practice today, provides a large amount of meat.

Although the social context in which people collect food has changed, the basic methods of food preparation have altered little from the descriptions provided by Tindale even with the use of introduced items such as billycans. Fish are either put straight onto wood charcoal coals or wrapped in paperbark and cooked in an oven pit. Sometimes they are boiled up in a billycan. Shellfish are eaten raw, steamed open on the charcoal coals or boiled in the billycan. Yams and Eleocharis dulcis corms and yams are roasted and turtles are still cooked much as Tindale and others have described.

\section{BUSH CAMPS, MOBILITY AND CONTACT WITH THE MAINLAND}

There were several issues concerning camps, mobility and contact with the mainland that I wanted to examine through the Mission archives. I wanted to see if there were any comments about particular groups leaving their traditional country to come into the Mission, where people camped when they left the Mission, how often and what time of the year people went back into the bush and whether people maintained trading links with the mainland.

Unfortunately, there was very little information about specific campsites either in terms of names or general locations, and the missing records from the Emerald River meant that there was no primary information on missionary interactions with Groote Eylandt people between 1921 and 1939. There are a few general localities mentioned as camping areas including the Emerald River, Wallaby Swamp and Bartalumba Bay. Rose recorded families camping at Lake Herbert (Angurrkwurrikba) in 1941. In 1948 McArthur camped with people at Hemple Bay. When she camped in South Bay on Bickerton Island people moved to join her from their camp on the West Bay where they had been for several months.

There was more information about the movement of people on and off the Angurugu Mission, and despite the patchy nature of these observations they do provide some insights about the mobility of people in the first fifteen years of its establishment on the Angurugu River.

Both the Berndts (Berndt and Berndt 1954: 191) and Worsley (1954: 264-271) write of the uneasy relationship between the local Aboriginal people, mainlanders and the missionaries during the initial phase of settlement. Following the Woodah Island murders in 1932 (Berndt and Berndt 1954; Thomson 1983; Dewar 1992; Egan 1996) the Mission was heavily barricaded with barbed wire in expectation of an attack by mainlanders. Berndt and Berndt (1954: 191) comment that eventually a permanent camp of the local population came to live around the Mission, coming into increasing contact with the missionaries.

Perriman (NTRS 226, TS102/2) notes that it was from around 1932 onwards that the Groote Eylandt Aboriginal people started to move into camps around the Mission. A dormitory for boys was constructed in 1934, and by 1936 some girls were going to school at the Mission. From 1937 some families began to live around the Mission on a fulltime basis. (Worsley 1954: 271)

The monthly reports do not contain a lot of detail about people moving on and off the Mission but there are a few accounts, which give an indication of the mobility of some groups, particularly Bickerton Islanders. The accounts do, however, provide evidence of a regular and patterned movement of people between Angurugu and Bickerton Island, as can be seen from the following examples:

Kevin Hoffman and self went to Bickerton Island in 'Victory'. A service was held in the beach the following morning about 60 natives being present. These natives had been on Walkabout from the mission and most of them returned to the Station on the return trip of Victory. (G.R. Harris, 8 April 1949, NTRS 1098/P1)

There is a noticeable difference in the figures for this month both for endowment and employment of natives. The explanation is found in the return of the Bickerton Islanders to their own country. This is an annual occurrence and the period of their absence is generally three months. (July 1951, R.V. Ash, NTRS 1098/P1)

There are also notes about Bickerton people going to the mainland and Nungubuyu people coming over from the Rose River. The Rose River people come over to trade for goods and some families stayed at the Mission:

During the month the Bickerton men expressed the desire to spend some time on Bickerton and 
on the mainland and it was agreed that the people generally have one weeks walkabout during which time many of the Yediba people also went walkabout. Some men with Nungubuyu connections journeyed across to the Rose River leaving some of their wives behind for medical treatment. (September 1953, K. Hoffman, NTRS 1098/P1)

This 1953 account provides a contrast to the statement made only two years earlier that the Bickerton men went back to their country for up to three months a year. Turner (1974: 11) notes that during the 1940s the population became increasingly sedentary, leaving the Mission only for short periods. In 1942 he states that each person made on average three visits to the Mission of three months duration over the course of the year. By 1949 this pattern had reversed and many people were spending up to ten months of the year on the mission.

One pattern that is apparent from the limited archival information is how Bickerton people, in particular, appeared to incorporate the Mission into a seasonal routine of land use. Men regularly spent the early dry season on Bickerton (see below) travelling periodically between the Mission, Bickerton and the mainland over the remainder of the dry. People were more sedentary in the wet season, staying around the Mission. This is a similar pattern of residence to that established during the period of Macassan visits when people would gather around the Macassan camps, working for goods over the wet season and dispersing when the Macassan fleets departed at the beginning of the dry season. Eventually, as noted above, this seasonal migration away from the Mission diminished in length and became confined to official holiday periods.

People still move between Angurugu, Bickerton and the mainland on a regular basis. Today, however, the mode of transport is a charter plane rather than a dugout canoe, and visits are more likely to take place on weekends and during school holidays.

\section{TECHNOLOGY}

There were two aspects concerning the use of technology that I was interested in. Firstly, whether wooden or stone artefacts were used in traditional or new contexts and secondly, how introduced materials and tools were used. There was, however, very little primary information about technology.

Perriman (NTRS 226, TS 102/1: 7) recalls how people brought in turtle shell which the missionaries bought and then sold at Thursday Island with the proceeds used to buy tobacco and other stores. People would also purchase fencing wire to make spears and nails to make hooks. He comments that tins were highly prized and that people began to wear cloth coverings rather than pubic tassels. He also notes that the Mission's most costly purchases were butchers' knives and tomahawks, which were in great demand.

The most frequent reference to technology involves canoe making. There are accounts of canoe making at three different locations, the Emerald River, Wallaby Swamp and the Amagula River. Tindale recorded canoes being cut at Emerald and Angurugu Rivers. Perriman (NTRS 226, TS 102/1: 7) recalls that people would borrow the mission canoe in exchange for four fish a day.

There is an interesting account from 1953 when the men were encouraged to use hollow trees rather than whole trees to make their canoes. This is in direct contrast to the process of tree selection observed by Tindale (1925-26: 104-105) who noted how trees with hollows or any internal decay were rejected. The change in the technique of canoe making may be due to a greater demand for canoes as the Mission population grew, but the account also demonstrates the technological flexibility and adaptability of people once they were given access to caulking materials to patch the hulls of the hollow trees:

We commenced cutting canoes in June, and July brought to a conclusion a plan that was evolved to assist native men cut their new canoes. The canoes were all cut at Wallaby Swamp, 16 miles from the Mission, and for two weeks during the month occupied most of the men on the Station. For the first time the natives have used trees that were hollow and otherwise rejected material, but with Gerry's assistance the canoes were patched and now performing perfectly. We presume it takes at least two hundred years for a giant paperbark to mature and rather than see more trees wasted we hope that those once rejected hollow trees have now regained value. (K.D. Hoffman, July 1953, NTRS 1098/P1)

By 1952/1953 Worsley (1954: 354-355) was able to observe that the changes since the establishment of the Mission and Umbakumba settlement were reflected in the manufacture of artefacts and craft items. He noted that in Tindale's photographs artefacts in everyday use, such as spear throwers or paddles, were elaborately decorated and carefully crafted from specific woods, but were by the 1950s roughly shaped from any available wood and left undecorated. He saw the decay in traditional arts and crafts as a metaphor for the rapidly disappearing Indigenous institutions, relating to a general lack of enthusiasm among people for life as constituted by the settlement. 
Another transformation of technology was the production of artefacts as craft items for sale. In 1954 a trading store was established at Angurugu (NTRS 1098/P1) where people could bring in craft items and get paid in store goods and later in cash. This may have gradually re-established the production of decorated and elaborate artefacts and created a group of specialist craft workers.

Worsley (1954: 13, 74-81) considered that one consequence of Macassan contact was that it stimulated people to produce more goods in order to exchange them rather than for immediate use or consumption. With the establishment of the Mission this became a permanent feature of the Aboriginal economy. Prior to Macassan contact, labour and technology operated primarily in the realm of utility being directed towards the maintenance of established patterns of residence, resource use and exchange networks based on kinship relationships (Worsley 1955). As result of prolonged contact, firstly with the Macassans and secondly with the missionaries, labour and technology became increasingly directed towards obtaining and producing commodities, firstly as barter-based exchange and more recently within a cash economy (Turner 1974).

During the period of Macassan contact and the first years of Mission settlement the commoditybased exchange system engaged Groote Eylandters in a number of levels of social interaction. At the local level people supplied bush foods and occasionally their labour in return for extractive tools such as axes, knives and fish hooks which were used in the maintenance of the local subsistence system. These introduced tools were used to manufacture spears and other items, which entered the regional exchange system on the mainland (Thomson 1949). The local and regional levels of interaction directly involved Groote Eylandt people. In this period of contact people also became engaged, albeit less directly, with the wider economy.

In the mission period Groote Eylandt people became increasingly involved with this wider level of trade. Both Balamumu and Groote Eylandt people traded pearl and trochus shell with the missionaries. These goods were sent to Thursday Island where they were exchanged for currency by the missionaries and used to purchase the tobacco, axes and other goods in demand on the island. Metal tools were also used to manufacture craft artefacts, which were firstly sold for credit at the trading store and then to buyers in the major cities.

\section{CONTINUITIES AND CHANGES}

The historical sources have provided an outline of the rapid transformation of aspects of the
Indigenous economy on Groote Eylandt over a period of less than 50 years. During this time Groote Eylandt society underwent a process of transformation from mobile hunter-gatherers with a broad spectrum economy incorporating a trade and exchange system based on kinship, to sedentary, part-time hunter-gatherers with a highly targeted economy operating within the framework of a commodity-based trade and exchange system. Changes and continuities in resource use and residence patterns identified for the first 35 years of Mission settlement can be divided broadly into two phases.

The first phase covers the time when the Emerald River Mission Station was set up from 1921 to around 1932-1934. In this period people began to move into the vicinity of the Mission, altering their normal patterns of residence and mobility to take advantage of the year round access to Mission goods. People began to abandon areas of the archipelago most remote from the Mission. The far south-east of the island may have been largely depopulated during this initial phase of settlement. Turner (1973) noted the lack of Mission inspired paintings in this area and attributed this to people moving to the west coast. This shifting of population may have been one of the contributing factors to the amount of fighting between groups noted by the missionaries. The earlier presence of Macassans may have already set up a situation where people moved into land belonging to other clans in larger numbers and for longer periods than in the pre-Macassan period.

The Groote Eylandters did not receive Mission food stores during this period and still operated a broad spectrum subsistence system, although the west coast around the Mission may have been more intensively exploited over this time. Introduced items and materials were primarily used in traditional contexts for the maintenance of the subsistence system and the regional exchange network.

The next phase occurred when Groote Eylandters were taken onto the Mission in place of the Roper River children. In this period, from the early 1930s until the early 1950s, people still operated within the broad parameters of their previous patterns of regional movement, resource use, trade, exchange and ceremony but they began to settle for increasingly longer periods around the Mission and Umbakumba. Bickerton Islanders continued to return to their own country although by the end of this period trips had contracted from three or more months to around one week. The pattern of weekend and holiday-time hunting and gathering began in this period. In 1954 a monetary economy was introduced and a trading store and sales store were set up. The mission report for June 1954 
records the showing of a film about the use and value of money (NTRS 1098/P1). Turner (1974: 179_ 182) produced a detailed analysis of the impacts of these economic changes on people at Angurugu and noted how people gradually became more accustomed to and desirous of the same goods, services and luxuries as their white counterparts and how they were willing to take on an increasing amount of paid employment to achieve these desires.

By using the early historical accounts, the CMS archives and the more formal anthropological accounts of Groote Eylandt society from 1921 to the 1970s it is possible to track changes in aspects of Indigenous economic life across the period prolonged and more intensive engagement with outsiders. The approach adopted in this study demonstrates that such sources need not be seen primarily as records of loss, and used only as texts to reconstruct past lifeways, but can also be seen as powerful narratives of how Indigenous communities negotiated the challenges presented by the incursion of western society into their daily lives.

\section{REFERENCES}

Berndt, R. and Berndt, C. (1954). Arnhem Land: its history and its people. F.W. Cheshire: Melbourne.

Bourke, P. (2000). Late Holocene Indigenous economies of the tropical Australian coast: an archaeological study of the Darwin region. PhD Thesis, Northern Territory University: Darwin.

Brockwell, C.J. (2001). Archaeological settlement patterns and mobility strategies on the Lower Adelaide River, Northern Australia. PhD Thesis, Northern Territory University: Darwin.

Clarke, A. (1994). Winds of change: an archaeology of contact in the Groote Eylandt archipelago, Northern Australia. PhD thesis, The Australian National University: Canberra.

Clarke, A. (2000a). Time, tradition and transformation: the archaeology of intercultural encounters on Groote Eylandt, Northern Australia (pp. 142-181). In: Torrence, R. and Clarke, A. (eds), The archaeology of difference: negotiating cross-cultural engagements in Oceania. One World Archaeology 38, Routledge: London.

Clarke, A. (2000b). The Moormans Trowsers: Aboriginal and Macassan Interactions and the changing fabric of Indigenous social life. In: O'Connor, S. and Veth, P. (eds), East of Wallace's Line. Modern Quaternary Research in east Asia 16: 315-335. A.A. Balkema: Rotterdam.

Clarke, A. and Frederick, U. (2006). Closing the distance (pp. 116-133). In: Lilley, I. (ed.), The archaeology of Oceania: Australia and the Pacific islands. Blackwell: Oxford.

Cole, K. (1971). Groote Eylandt pioneer, a biography of the Reverend Hubert Ernest de Mey Warren, pioneer missionary and explorer among the Aborigines of Arnhem Land. Church Missionary Historical Publications
Trust: Melbourne.

Cole, K. (1972). Groote Eylandt stories, changing patterns of life among the Aborigines on Groote Eylandt. Church Missionary Historical Publications Trust: Melbourne

Cole, K. (1983). Groote Eylandt, changing Aboriginal life styles. Revised edition. Keith Cole Publications: Bendigo.

Dewar, M. (1992). The 'Black War' in Arnhem Land: missionaries and the Yolngu 1908-1940. Australian National University, North Australian Research Unit: Darwin.

Faulkner, P. (2006). The ebb and flow: an archaeological investigation of Late Holocene economic variability on the coastal margin of Blue Mud Bay, Northern Australia. PhD Thesis, Australian National University: Canberra.

Flinders, M. (1814). A voyage to Terra Australis. London.

Egan, T. (1996). Justice all their own: the Caledon Bay and Woodah Island killings 1932-1933. Melbourne University Press: Carlton.

Hiscock, P. (2008). Archaeology of ancient Australia. Routledge: London, New York.

Jones, R. and White, N. (1988). Point blank: stone tool manufacture at the Ngilipitji Quarry, Arnhem Land, 1981 (pp 51-87). In: Meehan, B. and Jones, R. (eds), Archaeology with ethnography: an Australian perspective. Department of Prehistory, Research School of Pacific Studies, Australian National University: Canberra.

Levitt, D. (1981). Plants and people. Aboriginal uses of plants on Groote Eylandt. Australian Institute of Aboriginal Studies: Canberra.

Macknight, C.C. (1969). The farthest coast: a selection of writings relating to the history of the northern coast of Australia. Melbourne University Press: Melbourne.

Macknight, C.C. (1972). Macassans and Aborigines. Oceania 42: 283-319.

Macknight, C.C. (1976). The voyage to Marege'. Macassan trepangers in northern Australia. Melbourne University Press: Melbourne.

McArthur, M. (1960a). The report of the nutrition unit (pp. 1-26). In: Mountford, C.P. (ed.), Records of the American-Australian scientific expedition to Arnhem Land. Volume 2, anthropology and nutrition. Melbourne University Press: Melbourne.

McArthur, M. (1960b). Food consumption and dietary levels of groups of Aborigines living on naturally occurring foods (pp. 90-135). In: Mountford, C.P. (ed.), Records of the American-Australian scientific expedition to Arnhem Land. Volume 2, anthropology and nutrition. Melbourne University Press: Melbourne.

McCarthy F.D. and McArthur, M. (1960). The food quest and the time factor in Aboriginal economic life (pp. 145-194). In: Mountford, C.P. (ed.), Records of the American-Australian scientific expedition to Arnhem Land. Volume 2, anthropology and nutrition. Melbourne University Press: Melbourne.

Mitchell, S. (1994). Culture contact and indigenous economies on the Cobourg Peninsula, north western Arnhem Land. PhD Thesis, Northern Territory University: Darwin.

Mitchell, S. (1996). Dugongs and dugouts, sharptacks and shellbacks: Macassan contact and Aboriginal marine hunting of the Cobourg Peninsula north western 
Arnhem Land. Bulletin of the Indo-Pacific Prehistory Association 15: 181-191.

Meehan, B. (1982). Shell bed to shell midden. Globe Press: Melbourne.

Morwood, M.J. and Hobbs, D.R. (1997). The Asian connection: preliminary report on Indonesian trepang sites on the Kimberley coast. Archaeology in Oceania 32: 197-206.

Mulvaney, D.J. (1975). The prehistory of Australia. Penguin: Melbourne.

Mulvaney, D.J. (1989) Encounters in place: outsiders and Aboriginal Australians 1606-1985. University of Queensland Press: Brisbane.

Mulvaney, D.J. and Green, N. (1992). Commandant of solitude. Melbourne University Press: Melbourne.

Rose, F.G.G. (1987). The traditional mode of production of the Australian Aborigines. Angus and Robertson: Sydney.

Thomson, D. (1949). Ecomomic structure and the ceremonial exchange cycle in Arnhem Land. McMillan: Melbourne.

Thomson, D. (1983). Donald Thomson in Arnhem Land. Currey O'Neil Ross: Melbourne.

Tindale, N.B. (1925-1926). Natives of Groote Eylandt and of the west coast of the Gulf of Carpentaria. Parts 1-2. Records of the South Australian Museum 3: 61-143.

Turner, D.H. (1973). The rock art of Bickerton Island in comparative perspective. Oceania 43: 286-325.

Turner, D.H. (1974). Tradition and transformation: a study of Aborigines in the Groote Eylandt area, Northern Australia.
Australian Aboriginal Studies No. 53. Australian Institute of Aboriginal Studies: Canberra.

Warner W.L. (1932). Malay influence on Aboriginal cultures of north-eastern Arnhem Land. Oceania 2: 476-495.

Wilkins, G.H. (1928). Undiscovered Australia. Ernest Benn: London.

Worsley, P.M. (1954). The changing social structure of the Wanindiljaugwa. PhD Thesis. Australian National University: Canberra.

Worsley, P.M. (1955). Early Asian contacts with Australia. Past and Present 7: 1-11.

\section{ARCHIVAL SOURCES - NORTHERN TERRITORY ARCHIVES SERVICE DARWIN}

NTRS 1098/P1 Mission Reports and station council minutes of the Angurugu community, 1939-1979.

NTRS 1011 Mission reports and station council minutes of the Umbakumba Community, 1958-1970.

NTRS 693 Alfred J. Dyer (Rev) Records relating to mission life in Northern Australia, 1907-1966.

NTRS 868 Correspondence and community records, Angurugu and Emerald River, 1921-1985.

NTRS 226 Typed transcripts of oral history interviews with 'TS' prefix 1979-ct.

MANUSCRIPT RECEIVED DECEMBER 2005; ACCEPTED NOVEMBER 2006. 